\title{
An alternative experimental model for training in microsurgery
}

\section{Modelo experimental alternativo para treinamento em microcirurgia}

\author{
Ivan Maluf Junior, AsCBC-PR 1; Alfredo Benjamin Duarte da Silva ${ }^{2,3}$; Anne Karoline Groth'²; Marlon Augusto Camara Lopes'; \\ Adriana Sayuri Kurogi ${ }^{1}$; Renato da Silva Freitas ${ }^{1}$; Flávio Daniel Saavedra Tomasich, TCBC-PR ${ }^{3}$
}

A B S T R A C T

\begin{abstract}
Objective: to describe a new model of training in microsurgery with pig spleen after splenectomy performed by undergraduate students of the Discipline of Operative Technique of the UFPR Medical School. Methods: after the completion of splenectomy we performed dissection of the vascular pedicle, distal and proximal to the ligation performed for removal of the spleen. After complete dissection of the splenic artery and vein with microscope, clamps were placed and the vessels were cut. We then made the anastomosis of the vessels with 9.0 nylon. Result: the microsurgical training with a well-defined routine, qualified supervision and using low cost experimental materials proved to be effective in the practice of initial microvascular surgery. Conclusion: the use of pig spleen, which would be discarded after splenectomy, is an excellent model for microsurgical training, since besides having the consistency and sensitivity of a real model, it saves the sacrifice of a new animal model in the initial learning phase of this technique.
\end{abstract}

Key words: Training. Techniques. Surgical procedures, operative. Microsurgery. Models, anatomic.

\section{INTRODUCTION}

T he importance of the application of microsurgery in plastic surgery is due in large part to the use of free flaps. This technique allows for reimplantation of fingers, hands, limbs, ears, penis, and other body segments'.

In Brazil, there is great need for microsurgeons due to the costs involved in training and shortage of services that offer specialized training. The training in microsurgery is long, expensive and requires a high degree of dedication. The complete mastery of the microsurgery techniques must be obtained in the laboratory before being used in clinical practice ${ }^{2}$.

There are various training models involving different materials and animals. Some training routines have also been defined in order to obtain adequate vascular permeability and therefore success in daily practice ${ }^{3}$.

The use of synthetic material, such as silicone, is quite practical for initial training, but has the disadvantage of not providing structures of consistency similar to biological tissues and not allowing training of dissection techniques. Several inert animal parts can be used for training, such as chicken's feet, easily obtainable in places where they are offered for consumption, of low cost and easy storage. We attribute to this step the importance of learning how to manipulate and feel the delicacy of microvascular structures when performing dissection and microsuture without the presence of the stressor, which could occur initially in working with live animals. The latter are sensitive to many factors, such as small volume loss, prolonged surgical time and inadvertent injury by training without enough experience, easily causing animals death, which could increase the costs of training ${ }^{3,4}$

The goal of this article is to demonstrate the experience of the Plastic Surgery Service of the Clinics Hospital of UFPR in training in microsurgery with pig spleen after splenectomy performed by undergraduate students of the Medical School.

\section{METHODS}

We describe a model for microsurgical training in which we use the spleen of post mortem pigs after splenectomy performed by students of Medical Surgical Technique, UFPR (Figure 1). All procedures were previously approved by the Institutional Ethics Committee. The work is performed only after the splenectomy is carried out by the Medical graduates. There is no contact with the living animal, just with the specimen removed.

\footnotetext{
1. Plastic and Reconstructive Surgery, Clinics Hospital, Federal University of Paraná (UFPR), Curitiba, PR, Brazil; 2. Plastic Surgery Service, Erastus Gaertner Hospital, Curitiba - PR; Discipline of Experimental Surgery and Operative Technique, Department of Surgery, Federal University of Paraná; 3. Plastic Surgery Service, Erastus Gaertner Hospital, Curitiba - PR - Brazil. 4. Discipline of Experimental Surgery and Operative Technique, Department of Surgery, Federal University of Paraná.
} 
The operation begins with the dissection of the distal vascular pedicle next to the pedicle ligation performed at splenectomy. After complete dissection of the splenic artery and vein, with microscope, clamps are placed and each vessel is cut. Anastomosis of the vessels is then performed with 10-0 BV nylon (Figures 2, 3 and 4).

The instruments used for microvascular anastomosis consists of jeweler microforceps, micro-scissors, microclips, clip holder, retractors and monofilament stitches. We use 10-0 stitches to vessels with a diameter of $1.0 \mathrm{~mm}$, and 9-0 for vessels with a diameter of $2.0 \mathrm{~mm}$.

The caliber of the splenic vessels found ranged from 1.5 to $2.5 \mathrm{~mm}$, depending on the size of the animal. This enabled the training of microsurgical anastomoses in vessels of different calibers. These vessels remained with small amount of blood in the lumen, which allowed testing the quality and patency of the anastomosis.

\section{DISCUSSION}

In microsurgery training routines are defined in order to obtain adequate vascular permeability and, consequently, success in everyday practice. The microsurgical training with a well-defined routine, qualified supervision, and using low cost experimental materials, proved effective in initial microvascular surgery practice. It provides the surgeon with the acquisition of theoretical knowledge and skill to satisfactory completion of the procedures with good levels of vascular permeability, which must be obtained prior to optimization in the clinical and surgical practice ${ }^{5}$.

Clinical trials for the practice of microsurgical anastomoses are limited to those in the training process, although there are several animal models (rats, pigs and chickens). Strict laws on Institutional Committees for the Care and Use of Animals also hinder the process of medical education. This makes it necessary to develop alternatives to existing models of training. Artificial materials (silicone tubes, gloves), simulators and robots have been described as helper methods in basic skills training in microvascular anastomosis procedures. However, each of these methods can be improved in terms of accessibility, reliability and cost-effectiveness ${ }^{5}$.

In Brazil, in most states there are no training centers or regular microsurgery courses. In this context, a major obstacle is the cost of training, which does not diminish the importance of the existence of regional microsurgery centers, as in emergency cases, such as traumatic amputation, time of transfer to a reimplantation reference center is short and not feasible ${ }^{6}$.

Initial training in microsurgery can be long and tedious if there is no plan to accomplish it. The training should be first in an environment that does not involve patients, due to the complexity it represents. It has been

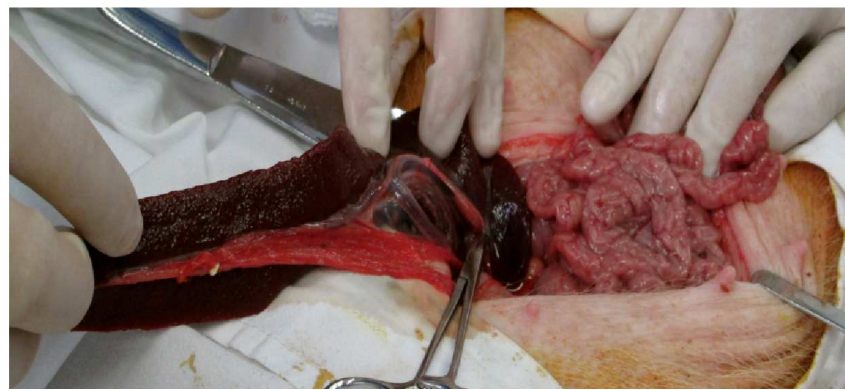

Figure 1 - Splenectomy being performed by UFPR medical students.

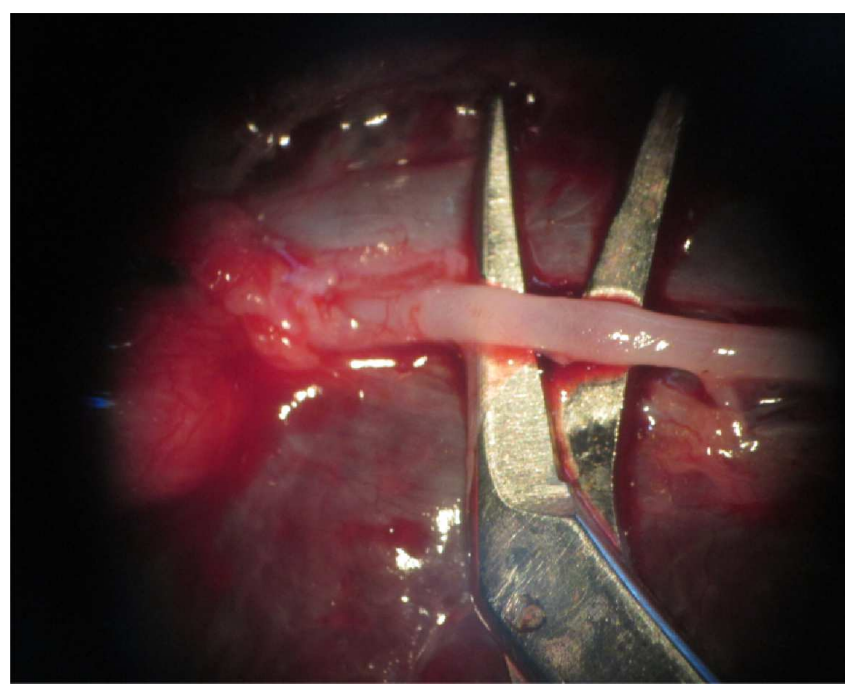

Figure 2 - $\quad$ Picture of the dissected splenic artery.

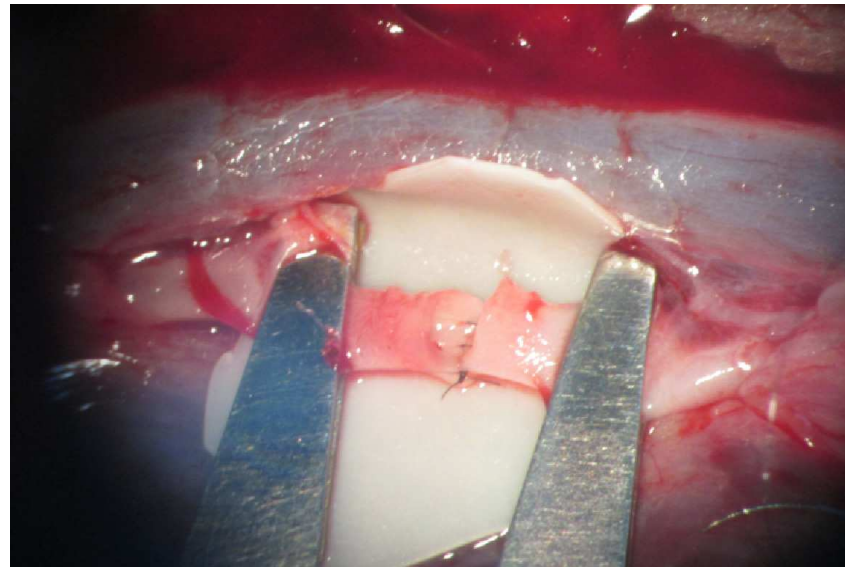

Figure 3 - Image of the open posterior wall and suturing of the anterior wall of the vessel.

observed that at each stage training becomes more stimulating, due to the perception of the practical evolution that training itself

The use of porcine spleen as a training model allows surgeons undergoing training to develop their surgical skills in a very realistic way. The cost is extremely low when compared with the use of animals or simulators and enables faster and more real transition to patients. The practice of 


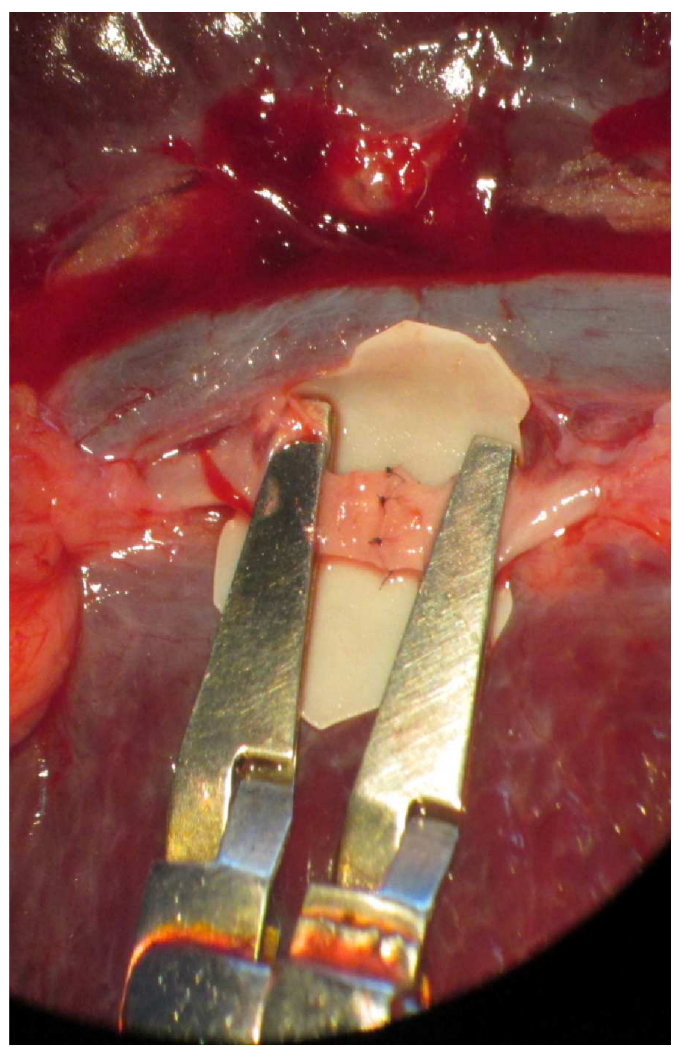

dissection and terminoterminal and terminolateral anastomosis is performed in an effective manner.

People who work with animals in research, in teaching or in laboratory testing shall value animal life, consider them beings, seek to reduce the suffering and have a responsibility to ensure that the care given to the animals is always of excellent quality. Therefore, the use of the pig spleen, which would be discarded after splenectomy, is an excellent model for microsurgical training, as it has the consistency and sensitivity of a real model and saves the sacrifice of a new animal model at the initial learning phase

Figure 4 - $\quad$ Picture of the splenic artery with 10-0 nylon stitches.

\section{R E S U M O}

Objetivo: descrever um novo modelo de treinamento em microcirurgia com baço de suínos após esplenectomia realizada pelos alunos de graduação da disciplina de técnica operatória do curso de medicina da UFPR. Métodos: após a realização da esplenectomia realizamos dissecção do pedículo vascular distal e proximal a ligadura realizada para a retirada do baço. Após a dissecção completa da artéria e veia esplênica ,com microscópio, são colocados os clampes e o vaso é seccionado. É então realizada a anastomose dos vasos com mononylon 9,0. Resultado: o treinamento microcirúrgico, com uma rotina bem definida, supervisão qualificada e utilizando materiais experimentais de baixo custo, mostrou-se efetivo na prática de cirurgia microvascular inicial. Conclusão: a utilização do baço suíno, que seria desprezado após esplenectomia, é um excelente modelo para treinamento microcirúrgico, pois além de ter a consistência e delicadeza de um modelo real poupa o sacrifício de um novo modelo animal, na fase inicial de aprendizado desta técnica.

Descritores: Treinamento. Técnicas. Procedimentos cirúrgicos operatórios. Microcirurgia. Modelos cirúrgicos.

\section{REFERENCES}

1. Viterbo F. Importância da microcirurgia na cirurgia plástica. Rev Bras Cir Plast. 2012;27(1):2.

2. Martins PNA, Montero EFS. Basic microsurgery training: comments and proposal. Acta Cir Bras. 2007;22(1):79-81.

3. Lima DA, Galvão MSL, Cardoso MM, Leal PRA. Rotina de treinamento laboratorial em microcirurgia do Instituto Nacional do Câncer. Rev Bras Cir Plast. 2012;27(1):141-9.

4. Fraga MFP, Perin LF, Green AC, Zacarias R, Faes JC, Tenório T, et al. Practical training model for microvascular anastomosis. Rev Bras Cir Plast. 2012;27(2):325-7.

5. Webster R, Ely PB. Treinamento em microcirurgia vascular: é economicamente viável? Acta Cir Bras. 2002;17(3):194-7.

6. Isolan GR, Santis-Isolan PMB, Dobrowolski S, Cioato MG, Meyer FS, Antunes ACM, et al. Considerações técnicas no treinamento de anastomoses microvasculares em laboratório de microcirurgia:[revisão]. J bras neurocir. 2010;21(1):8-17.

Received on 03/09/2012

Accepted for publication 06/11/2012

Conflict of interest: none.

Source of funding: none.

\section{How to cite this article:}

Maluf Júnior I, Silva ABD, Groth AK, Lopes MAC, Kurogi AS, Freitas RS, Tomasich FDS. An alternative experimental model for training in microsurgery. Rev Col Bras Cir. [periódico na Internet] 2014;41(1). Disponível em URL: http://www.scielo.br/rcbc

\section{Address for correspondence:}

Ivan Maluf Júnior

E-mail: ivanmalufjr@yahoo.com.br 